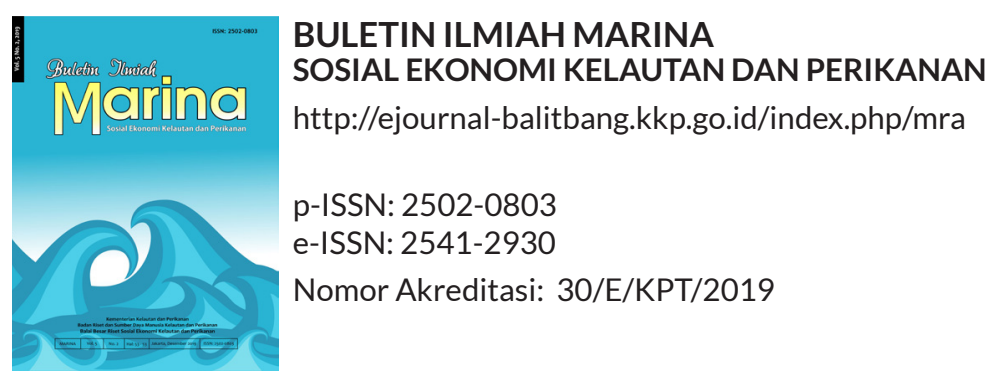

\title{
KONSUMSI IKAN DAN UPAYA PENANGGULANGAN STUNTING DI PROVINSI DAERAH KHUSUS IBUKOTA JAKARTA
}

\section{Fish Consumption and Stunting Prevention in Jakarta Province}

\author{
*Freshty Yulia Arthatiani dan Armen Zulham \\ Balai Besar Riset Sosial Ekonomi Kelautan dan Perikanan \\ Gedung BRSDM KP I Lt. 4, Jln. Pasir Putih Nomor 1 Ancol Timur, Jakarta Utara, Indonesia \\ Telp: (021) 64711583 Fax: 64700924 \\ Diterima tanggal: 11 Agustus 2019 Diterima setelah perbaikan: 5 Oktober 2019 \\ Disetujui terbit: 20 November 2019
}

\begin{abstract}
ABSTRAK
Konsumsi ikan dianggap sebagai salah satu solusi dalam penanggulangan pemasalahan gizi di Indonesia karena ikan merupakan sumber protein hewani yang dihasilkan oleh sumber daya alam di Indonesia. DKI Jakarta merupakan Ibukota Provinsi Republik Indonesia dengan penduduk yang sangat padat, sebagai pusat bisnis, pusat pemerintahan di Indonesia, yang dihuni oleh berbagai etnis dan golongan yang tinggal di wilayah tersebut. Akan tetapi angka stunting di DKI Jakarta masih cukup tinggi yaitu $23 \%$. Konsumsi ikan di DKI Jakarta tergolong rendah yakni sebesar 25,40 kg/kapita/tahun dibandingkan dengan konsumsi ikan nasional sebesar 47,34 kg/kapita/tahun pada Tahun 2017. Penelitian ini bertujuan untuk menyajikan hasil analisis konsumsi ikan di DKI Jakarta yang dikaitkan dengan wilayah kabupaten/ kota dan juga kelas pendapatan rumah tangga. Sumber data yang digunakan adalah SUSENAS (Survei Sosial Ekonomi Nasional) Tahun 2017 dengan responden berjumlah 5062 rumah tangga. Data analisis dengan menggunakan analisis deskriptif, untuk tingkat partisipasi dan tingkat konsumsi ikan rumah tangga. Hasil analisis menunjukkan bahwa tingkat partisipasi konsumsi ikan di DKI Jakarta sebesar 76,67\% dengan besaran konsumsi ikan tertinggi pada wilayah Kepulauan Seribu dan terendah adalah Jakarta Pusat. Oleh karena itu, strategi peningkatan konsumsi ikan yang dapat dilaksanakan adalah dengan peningkatan keterjangkauan dari ikan baik dari sisi harga maupun ketersediaanya. Selain itu, program edukasi dan promosi terhadap seluruh lapisan masyarakat perlu di lakukan. Jakarta Pusat seharusnya menjadi fokus wilayah peningkatan konsumsi ikan di DKI Jakarta karena rendahnya angka konsumsi ikan dan masih tingginya angka stunting di wilayah ini.
\end{abstract}

Kata Kunci: konsumsi ikan; partisipasi; rumah tangga; DKI Jakarta

\section{ABSTRACT}

Fish consumption is one solution to overcome nutritional problems in Indonesia for its animal protein sources. DKI Jakarta is the capital city and business center with a high population density inhabited by various ethnic and groups. However, the child stunting rate in Jakarta has remained high at 23\%. Fish consumption in Jakarta is relatively low at $25.40 \mathrm{kgs} / \mathrm{capital} / \mathrm{year}$ compared to national fish consumption of $47.34 \mathrm{kgs} / \mathrm{capital} / \mathrm{year}$ in 2017. This study aims to analyze fish consumption in Jakarta associated with areas and household income. Data were taken from SUSENAS (National Socio-Economic Survey) in 2017 with 5062 household respondents. The level of participation and fish consumption were analyzed by using descriptive analysis. The results shows that participation level of fish consumption in DKI Jakarta was $76.67 \%$ with the highest number was in the Thousand Islands region and the lowest number was in Central Jakarta. Therefore, the affordability of fish price and availability are necessary strategy to increase fish consumption as well as to encourage education and promotion programs for all levels of society. Central Jakarta should be the focused areas for increasing the fish consumption in DKI Jakarta due to its low number of fish consumption and the high stunting rate in this region.

Keywords: fish consumption; participation; household; DKI Jakarta 


\section{PENDAHULUAN}

Indonesia merupakan negara kepulauan dengan potensi dan produksi perikanan salah satu terbesar di dunia. Permasalahan gizi di Indonesia masih cukup memprihatinkan yang ditandai dengan tingginya angka stunting di negara ini. Berdasarkan data Kementerian Kesehatan Tahun 2016 menunjukkan persentase balita dengan kategori pendek dan sangat pendek atau biasa disebut stunting sebesar $29 \%$. Menurut WHO (2010) prevalensi balita stunting menjadi masalah kesehatan jika nilainya masih di atas $20 \%$ sehingga harus segera ditanggulangi. Balita stunting menjadi permasalahan karena berhubungan dengan meningkatnya risiko terjadinya kesakitan, kematian dan perkembangan otak suboptimal, sehingga perkembangan motorik terlambat dan terhambatnya pertumbuhan mental (Mitra, 2015). Oleh karena itu, penanganan stunting menjadi salah satu prioritas pembanguanan nasional yang tercantum dalam sasaran pokok rencana pembangunan jangka menengah Tahun 2015-2019. Salah satu upaya penanggulangan stunting yang menjadi program pemerintah adalah adanya program peningkatan konsumsi ikan nasional.

Konsumsi ikan nasional sebagai salah satu bahan pangan hewani dianggap dapat menjadi solusi masalah stunting karena menurut penelitian Wiseman (2002) menunjukkan bahwa, mengkonsumsi pangan hewani yang berkualitas dapat membantu pertumbuhan dan perkembangan setiap individu berjalan dengan sempurna sehingga mampu menciptakan generasi sumberdaya manusia yang berkualitas. Penelitian Suryanti \& Reswita ( 2016) menunjukkan, bahwa salah satu permasalahan penting konsumsi pangan Indonesia adalah masih sangat rendahnya kontribusi pangan sumber protein hewani dalam menu makanan sehari-hari. Hariyadi (2011) berdasarkan data dari Food and Agriculture Organization (FAO) menyimpulkan bahwa pada Tahun 2003-2005, konsumsi protein hewani per kapita/hari di Indonesia baru sekitar 20-30 gram, sedangkan di Thailand dan Filipina konsumsi protein hewani per kapita/hari berkisar antara 40-50 gram, selain itu Malaysia dan Brunei Darusalam sekitar 50-60 gram. Hal tersebut menunjukkan masih kurangnya konsumsi protein hewani di Indonesia. Indonesia sebagai Negara maritim dengan potensi dan produksi sumberdaya perikanan yang tinggi serta ketersediaanya sepanjang tahun membuat ikan menjadi pangan hewani utama yang memungkinkan untuk ditingkatkan konsumsinya.
Oleh karena itu peningkatan konsumsi ikan dalam upaya meningkatkan gizi penduduk Indonesia menjadi kebijakan yang diambil pemerintah melalui berbagai program.

DKI Jakarta merupakan menjadi salah satu provinsi terkaya di Indonesia dengan PDRB tertinggi yang ditunjukkan melalui kontribusi PDRB terhadap PDB nasional Tahun 2017 sebesar $17,07 \%$. Hal ini juga dibuktikan dengan nilai pengeluaran per kapita yang tertinggi secara nasional yakni sebesar Rp. 1.976.481/kapita/bulan (BPS, 2018). Disisi lain, DKI Jakarta ternyata masih menghadapi masalah gizi dengan prevalensi stunting mencapai 22,7\% (Kemenkes, 2017). Salah satu upaya untuk menurunkan prevalensi balita pendek adalah meningkatkan konsumsi pangan sumber protein. Menurut Aridiyah, Rohmawati \& Ririanty (2015) tingkat kecukupan protein dan kalsium menunjukkan hubungan yang signifikan untuk mencegah terjadinya stunting. Oleh karena itu, penelitian ini bertujuan menggambarkan tingkat konsumsi ikan di DKI Jakarta yang dikaitkan dengan wilayah dan kelas pendapatan dan angka stunting pada wilayah tersebut. Hasil penelitian diharapkan dapat merekomendasikan upaya peningkatan konsumsi ikan di DKI Jakarta dalam konteks upaya mengatasi masalah gizi di daerah ini.

Sumber data utama adalah data mentah SUSENAS modul konsumsi/pengeluaran dan modul karakteristik rumah tangga yang dikumpulkan oleh Badan Pusat Statistik Tahun 2017 dengan jumlah responden sebanyak 5.062 rumah tangga yang dianalisis pada Bulan FebruariSeptember Tahun 2019. Analisis dilakukan menurut wilayah administratif di provinsi DKI Jakarta yakni Kepulauan Seribu, Jakarta Selatan, Jakarta Timur, Jakarta Pusat, Jakarta Barat dan Jakarta Utara. Selain itu analisis konsumsi ikan juga dilakukan berdasarkan kelompok pendapatan yang didekati melalui total pengeluaran rumah tangga. Pengelompokkan pengeluaran rumah tangga mengikuti indikator World Bank (2014) sebagai berikut: (1) $40 \%$ kelompok pendapatan rendah, (2) $40 \%$ kelompok pendapatan sedang; dan (3) $20 \%$ kelompok pendapatan tinggi. Jenis ikan yang dianalisis adalah 35 jenis ikan sesuai ketersediaan data SUSENAS Tahun 2017 khususnya pada blok 4.1.C yakni konsumsi dan pengeluaran bahan makanan untuk ikan/udang/ cumi/kerang. Perhitungan konsumsi ikan per kapita dilakukan setelah dikonversikan dalam setara utuh segar sesuai dengan faktor konversi utuh segar yang dikeluarkan oleh Direktorat Pemasaran 
Kementerian Kelautan Perikanan Tahun 2017 (KKP, 2018) sesuai pedoman penyusunan NBM Badan Ketahanan Pangan.

Data yang telah diolah dianalisis secara deskriptif analitik berupa tabel-tabel. Informasi tingkat partisipasi konsumsi ikan diukur dengan menghitung rumah tangga yang mengkonsumsi ikan terhadap total rumah tangga yang dinyatakan dalam satuan persen (\%). Penggunaan pendekatan tingkat partisipasi konsumsi diharapkan dapat mengetahuitingkatkonsumsi efektifsuatu komoditas oleh cluster pengkonsumsinya (Soedjana, 2013). Tingkat konsumsi ikan dinyatakan dalam satuan $\mathrm{kg} / \mathrm{kap}$ ita/tahun. Selanjutnya, upaya perumusan strategi peningkatan konsumsi ikan dilakukan dengan metode desk study hasil kajian sebelumnya dan konsultasi dengan narasumber.

\section{KONDISI WILAYAH DAN KARAKTERISTIK RUMAH TANGGA DI DKI JAKARTA}

Provinsi DKI Jakarta memiliki luas daratan sebesar $662,33 \mathrm{~km}^{2}$ dan lautan seluas $6.977,5 \mathrm{~km}^{2}$ yang terbagi menjadi enam wilayah administrasi yakni Kepulauan Seribu, Jakarta Selatan, Jakarta Timur, Jakarta Pusat, Jakarta Barat dan Jakarta Utara. Wilayah administrasi terbagi menjadi 44 kecamatan dan 267 kelurahan. Jumlah penduduk DKI Jakarta Tahun 2017 berdasarkan proyeksi penduduk hasil Sensus Penduduk 2010 sebesar 10.374.235jiwa dengan laju pertumbuhan penduduk per tahun sebesar 0,94 persen. Kepadatan penduduk pada tahun 2017 adalah 13.663 jiwa setiap $1 \mathrm{~km}^{2}$ dengan kepadatan tertinggi di kota Jakarta Barat.

DKI Jakarta , Kepulauan Riau dan Kalimantan Timur merupakan tiga provinsi dengan rata-rata pengeluaran per kapita tertinggi di Indonesia (BPS, 2018). Pengeluaran rumah tangga terdiri atas dua kelompok yaitu pengeluaran pangan dan bukan pangan. Secara alamiah, kuantitas pangan yang dibutuhkan seseorang akan mencapai titik jenuh sementara kebutuhan bukan pangan tidak memiliki batasan. Oleh karena itu, besaran pengeluaran yang digunakan untuk pangan dari suatu rumah tangga dapat menjadi indikator kesejahteraan rumah tangga yang bersangkutan. Makin tinggi pangsa pengeluaran pangan semakin berkurang kesejahteraan rumah tangga yang bersangkutan. Untukmembandingkan tingkat kesejahteraan rumah tangga di DKI Jakarta dengan rata-rata secara nasional ditampikan tabel pangsa pengeluaran rumah tangga dapat dilihat pada Tabel 1.

Tabel 1 menjelaskan bahwa DKI Jakarta memiliki pangsa pengeluaran pangan jauh lebih rendah dibandingkan nilai rata-rata nasional yakni sebesar $38,97 \%$, sedangkan pangsa pengeluaran pangan nasional sebesar $52,45 \%$. Secara empiris terbukti bahwa semakin tinggi pendapatan rumah tangga semakin rendah pangsa pengeluaran untuk pangan (Pakpahan et al., 1993; Purwantini, 2012). Hal ini secara teoritis ditunjukan adanya hukum Working yang menyebutkan bahwa terdapat hubungan negatif antar pangsa pengeluaran pangan dengan pengeluaran total rumah tangga (Amaliyah, 2011). Sehingga dapat disimpulkan bahwa rumah tangga di DKI Jakarta memiliki kesejahteraan yang jauh lebih baik dibandingkan rata-rata rumah tangga lainnya di Indonesia.

Penelitian ini kemudian mengelompokkan lebih lanjut golongan pengeluaran rumah tangga tangga menggunakan kriteria Bank Dunia dibagi menjadi tiga kelas pendapatan. Berdasarkan kriteria tersebut maka menggunakan data pengeluaran rumah tangga di DKI Jakarta Tahun 2017 diperoleh data dapat dilihat pada Tabel 2.

Hukum Engel menyatakan bahwa saat pendapatan meningkat maka proporsi pendapatan yang digunakan untuk kebutuhan pangan akan berkurang. Selain itu, Engel juga menyimpulkan semakin kecil pangsa pengeluaran pangan maka menunjukkan semakin baik tingkat perekonomian rumah tangga tersebut. Berdasarkan Tabel 3 di atas diketahui bahwa semakin besar pendapatan maka semakin sedikit proporsi yang dibelanjakan untuk kebutuhan pangan. Oleh karena itu dapat disimpulkan bahwa hukum Engel berlaku untuk kondisi rumah tangga di DKI Jakarta dimana semakin tinggi kelas pendapatan dan semakin sejahtera suatu rumah tangga maka pangsa pengeluaran untuk kebutuhan pangan semakin

Tabel 1. Perbandingan Pangsa Pengeluaran Rumah Tangga di DKI Jakarta dan Nasional, 2017.

\begin{tabular}{lcccc}
\hline \multirow{2}{*}{ Jenis Pengeluaran } & \multicolumn{2}{c}{ DKI Jakarta } & \multicolumn{2}{c}{ Nasional } \\
\cline { 2 - 5 } & Total Nilai (Rp) & Persentase & Total Nilai (Rp) & Persentase \\
\hline Pangan & 2.914 .399 & 38,97 & 1.974 .890 & 52,45 \\
Non Pangan & 4.563 .464 & 61,03 & 1.790 .215 & 47,55 \\
Total & $\mathbf{7 . 4 7 7 . 8 6 3}$ & $\mathbf{1 0 0 , 0 0}$ & $\mathbf{3 . 7 6 5 . 1 0 5}$ & $\mathbf{1 0 0 , 0 0}$ \\
\hline
\end{tabular}


berkurang. Pangsa pengeluaran pangan terendah dimiliki oleh kelas pendapatan tinggi dimana hanya $27,33 \%$ alokasi pengeluaran rumah tangga yang digunakan untuk kebutuhan pangan.

Penelitian ini akan menganalisis konsumsi berdasarkan wilayah administratif di DKI Jakarta untuk dapat mengetahui secara lebih detail pola konsumsi antar wilayah dan kelas pendapatan. Oleh karena itu, gambaran umum pendapatan rumah tangga berdasarkan wilayah dapat dilihat pada Tabel 3.

Pada Tabel 3 menunjukkan bahwa dari sisi pengeluaran maka dapat dikatakan bahwa Kepulauan Seribu merupakan wilayah yang memiliki pendapatan paling rendah di DKI Jakarta yang ditunjukkan dengan pangsa pengeluaran yang lebih besar untuk pangan dibandingkan kebutuhan non pangan yakni sebesar $65,45 \%$. Selain itu jika dilihat dari banyaknya rumah tangga yang berada pada kelas pendapatan rendah maka Kepulauan Seribu memiliki rumah tangga kelas pendapatan rendah yang terbanyak yakni sebesar $54,84 \%$ dari total rumah tangga. Kota dengan pendapatan tertinggi adalah Jakarta Barat yang ditunjukkan dengan persentase terbesar pengeluaran dialokasikan untuk kebutuhan non pangan sebesar $64,30 \%$ dengan jumlah rumah tangga yang berada pada kelas pendapatan rendah sebesar $33,96 \%$. Karakteristik pengeluaran ini memiliki implikasi terhadap kemampuan daya beli penduduk di DKI Jakarta, pendapatan yang tinggi akan meningkatkan kemampuan untuk membeli barang-barang dengan kualitas baik sehingga seharusnya wilayah dengan pendapatan yang tinggi memiliki resiko lebih rendah menghadapi masalah gizi yang disebabkan oleh kurangnya asupan gizi. Hal ini sejalan dengan penelitian Purwaningsih (2008) dan Mayasari, Satria \& Noor (2018) yang menyatakan bahwa semakin tinggi daya beli maka rumah tangga akan semakin mudah mengakses pangan.

Permasalahan gizi yang dihadapi oleh penduduk di DKI Jakarta salah satunya adalah masih tingginya angka stunting yakni di atas $20 \%$ standar dari WHO (World Health Organization). Penyebab masalah stunting menurut Ni'mah \& Nadhiroh (2015) sangat beragam seperti pendapatan keluarga, pendidikan orangtua, jumlah anggota keluarga dan pengetahuan ibu tentang gizi dan jumlah anggota keluarga. Berdasarkan data status pemantauan gizi (Kemenkes, 2017) angka stunting kabupaten/kota di DKI Jakarta disajikan dalam Gambar 1.

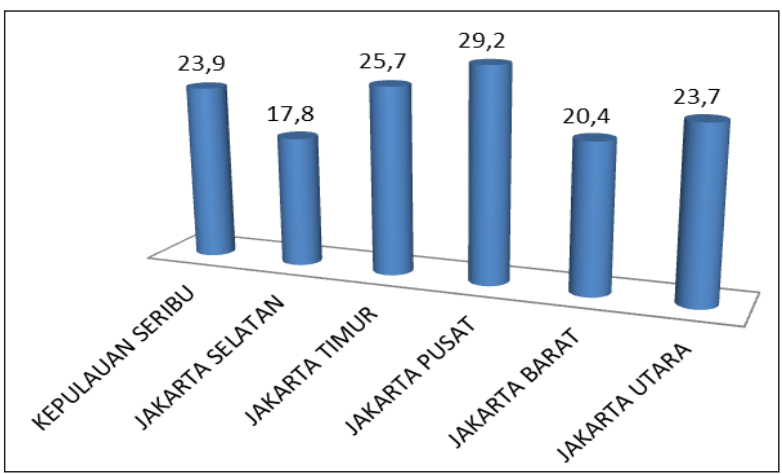

Gambar 1. Prevalensi stunting menurut Kabupaten/ Kota di DKI Jakarta.

Gambar 1 di atas menunjukkan bahwa hanya kota Jakarta Selatan yang prevalensi stuntingnya di bawah standar WHO yakni sebesar persen

Tabel 2. Kelas Pendapatan Rumah Tangga di DKI Jakarta, 2017.

\begin{tabular}{cccc}
\hline Kelas Pendapatan & $\begin{array}{c}\text { Rata-Rata Pengeluaran } \\
\text { (Rp/Bulan)/ }\end{array}$ & $\begin{array}{c}\text { Pangsa Pengeluaran } \\
\text { Pangan (\%) }\end{array}$ & $\begin{array}{c}\text { Pangsa Pengeluaran } \\
\text { Non Pangan (\%) }\end{array}$ \\
\hline Rendah & 2.891 .540 & 56,95 & 43,05 \\
Menengah & 6.219 .995 & 48,55 & 51,45 \\
Tinggi & 19.188 .123 & 27,33 & 72,67 \\
\hline
\end{tabular}

Tabel 3. Rata-Rata Pangsa Pengeluaran (\%) dan Rumah Tangga Kelas Pendapatan Rendah (\%) Berdasarkan Kabupaten/Kota Administrasi, 2017.

\begin{tabular}{cccc}
\hline Kabupaten/Kota Adm. & $\begin{array}{c}\text { Pangsa Pengeluaran } \\
\text { Pangan }\end{array}$ & $\begin{array}{c}\text { Pangsa Pengeluaran } \\
\text { Non Pangan (\%) }\end{array}$ & $\begin{array}{c}\text { Rumah Tangga Kelas } \\
\text { Pendapatan Rendah (\%) }\end{array}$ \\
\hline Kepulauan Seribu & 65,45 & 34,55 & 54,85 \\
Jakarta Selatan & 35,97 & 64,03 & 42,01 \\
Jakarta Timur & 44,18 & 55,82 & 40,47 \\
Jakarta Pusat & 40,68 & 59,32 & 43,13 \\
Jakarta Barat & 35,70 & 64,30 & 33,96 \\
Jakarta Utara & 36,14 & 63,86 & 37,59 \\
\hline
\end{tabular}


17,8 persen. Angka stunting tertinggi ditempati oleh wilayah Jakarta Pusat. Kepulauan Seribu, merupakan wilayah dengan pendapatan terendah akan tetapi nilai stuntingnya masih lebih baik dibandingkan dengan Jakarta Pusat dan Jakarta Timur. Penyebab langsung terjadinya balita stunting adalah kurangnya asupan makanan dan terpapar penyakit infeksi (Umeta, West, Verhoef, Haidar \& Hautvast, 2003). Hasil penelitian Sari, Juffrie, Nurani \& Sitaresmi, 2016 mengatakan bahwa asupan protein, kalsium dan fosfor signifikan lebih rendah pada anak yang stunting. Oleh karena itu, perlu dianalisis lebih lanjut bagaimana keragaan konsumsi ikan sebagai sumber protein hewani menurut wilayah di DKI Jakarta sehingga strategi dalam upaya mengatasi permasalahan gizi menjadi lebih optimal.

\section{KERAGAAN KONSUMSI IKAN ANTAR WILAYAH DAN PENDAPATAN}

Bagian sebelumnya telah menjelaskan kondisi kesejahteraan rumah tangga di DKI Jakarta dilihat dari pengeluaran rumah tangga dan pangsa pengeluaran terhadap pangan dimana jika dibandingkan secara nasional rumah tangga di DKI Jakarta lebih sejahtera dibandingkan rata-rata rumah tangga lainnya di Indonesia. Oleh karena itu dengan tingkat kesejahteraan yang lebih tinggi maka memiliki keterjangkauan ekonomi terhadap pangan yang lebih berkualitas. Saat ini kondisi di Indonesia menunjukkan bahwa konsumsi protein hewani masih perlu untuk ditingkatkan yang ditunjukkan dengan tingkat konsumsi protein hewani di Indonesia yang tergolong rendah dibandingkan Thailand, Filipina, Malaysia dan Brunei Darussalam (Hariyadi, 2015). Rachman \& Supriyati (2010) menyatakan bahwa kecerdasan dan kualitas suatu masyarakat berkorelasi positif dengan seberapa besar konsumsi protein hewani.
Kualitas konsumsi pangan hewani penting dalam upaya meningkatkan kualitas sumberdaya manusia di Indonesia. Ariani, Suryana, Suhartini \& Saliem (2018) dalam penelitiannya menyebutkan meskipun pangan hewani sangat penting untuk dikonsumsi akan tetapi tidak semua rumah tangga mampu mengkonsumsi jenis pangan ini karena rendahnya daya beli. Ikan merupakan sumber protein hewani utama yang ditunjukkan dengan kontribusi mencapai 40 persen dari seluruh protein hewani yang dikonsumsi penduduk Indonesia selama tahun 2005-2010 (BKP, 2012). Selain itu, ikan sangat potensial untuk ditingkatkan konsumsinya karena pemenuhannya dapat dilakukan dari potensi sumberdaya perikanan dalam negeri dan dengan jenis yang bervariasi memungkinkan harga yang variatif dapat dijangkau oleh berbagai kalangan. Oleh karena itu, penelitian ini menganalisis lebih lanjut keragaan konsumsi ikan di DKI Jakarta sebagai salah satu sumber protein hewani yang dijelaskan melalui Gambar 2.

Berdasarkan Gambar 2 maka dapat diketahui bahwa Jakarta Pusat merupakan wilayah dengan konsumsi ikan yang terendah ditunjukkan dengan nilai konsumsi ikan per kapita dan juga tingkat partisipasi konsumsi ikan yang relatif rendah hanya sebesar $58,29 \%$. Kepulauan Seribu memiliki konsumsi ikan per kapita yang tertinggi bahkan nilainya di atas nilai konsumsi ikan per kapita nasional. Hal ini dapat terjadi karena Kepulauan Seribu sebagian besar wiayahnya merupakan perairan sehingga banyak dikembangkan produksi perikanan dan membuat ikan menjadi komoditas pangan yang terjangkau. Pengolahan data juga menunjukkan secara agregat tingkat partisipasi konsumsi ikan di DKI Jakarta adalah sebesar $76,69 \%$ dan konsumsi ikan per kapita 29,37 kg/kapita/tahun. Banyak faktor yang dapat mempengaruhi pola konsumsi, berdasarkan

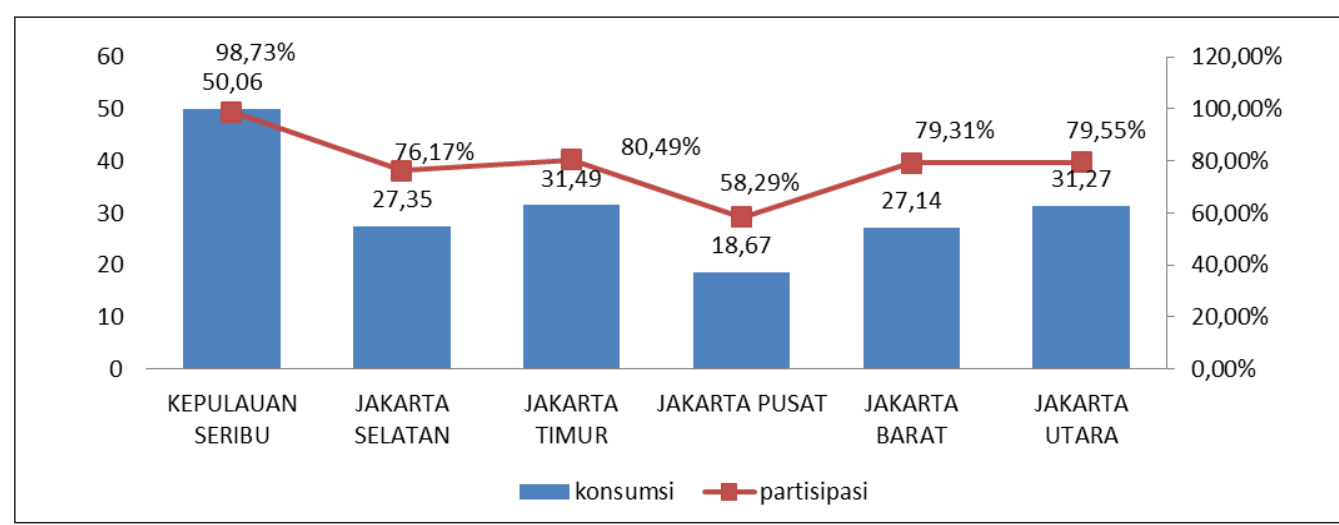

Gambar 2. Tingkat Partisipasi (\%) dan Rata-Rata Konsumsi lkan Rumah Tangga (Kg/Kap/Tahun) Menurut Kabupaten/Kota di DKI Jakarta, 2017. 
penelitian Aydin, Dileh \& Aydin, (2011) dan Ahmad et al. (2016) menunjukkan bahwa faktor yang mempengaruhi tingkat konsumsi ikan bervariasi mulai dari ciri demografi, lokasi geografis hingga aspek sosial ekonomi dan kebiasaan makan. Penelitian ini hanya mengkaji tingkat konsumsi dan tingkat partisipasi konsumsi ikan berdasarkan wilayah administratif yang juga dihubungkan dengan kelas pendapatan masyarakat sehingga faktor-faktor yang mempengaruhi tingkat konsumsi masih belum dapat terjawab dari penelitian ini. Analisis berikutnya akan menitik beratkan pada pola konsumsi ikan pada setiap kelas pendapatan. Hasil pengolahan data SUSENAS 2017 digambarkan melalui Tabel 4.

Berdasarkan data pada Tabel 4 maka dapat diketahui bahwa dari sisi tingkat partisipasi konsumsi ikan maka pada setiap wilayah di Provinsi DKI Jakarta memiliki pola yang sama yakni semakin meningkat partisipasinya dengan semakin tingginya kelas pendapatan. Hal ini sesuai dengan penelitian Dey, Alam \& Paraguas (2011); Baliwati \& Putri (2012) dan Arthatiani, Kusnadi \& Harianto (2018) dimana pada penelitian tersebut menunjukkan fenomena yang sama bahwa tingkat konsumsi ikan berhubungan positif dengan tingkat pendapatan. Tingkat partisipasi terendah dimiliki oleh kelas pendapatan rendah di wilayah Jakarta Pusat dengan persentase hanya 49,85 persen rumah tangga yang mengkonsumsi ikan dari total rumah tangga pada kelas pendapatan rendah di Jakarta Pusat. Akan tetapi jika dilihat dari tingkat konsumsi ikan per kapitanya yang memiliki nilai paling rendah justru pada kelas pendapatan menengah di Jakarta Pusat dengan nilai konsumsi hanya sebesar $16,88 \mathrm{~kg} / \mathrm{kapita} /$ tahun. Hal ini sangat jauh dari angka konsumsi ikan nasional sebesar 47,12 kg/kapita/tahun (KKP, 2017). Berdasarkan kondisi tersebut maka dapat disimpulkan bahwa untuk penduduk di Jakarta Pusat faktor pendapatan dan daya beli terhadap ikan tidak berhubungan secara langsung dengan tingkat konsumsi ikan. Permasalahan gizi stunting yang masih ditemui di DKI Jakarta yang dijelaskan melalui bahasan sebelumnya pada Gambar 1 seharusnya dapat diatasi dengan meningkatkan asupan gizi ibu, calon ibu dan balita di DKI Jakarta yang salah satunya dapat melalui peningkatan konsumsi ikan sebagai sumber protein hewani. Pada kenyataanya, ikan sebagai sumber pangan berkualitas tidak menjadi pilihan khususnya bagi penduduk di Jakarta Pusatmeskipun dari sisi keterjangkauan ekonomi mereka mampu untuk membeli ikan yang terlihat dari rata-rata tingkat konsumsi ikan yang rendah pada semua kelas pendapatan sehingga dapat dikatakan ikan tidak elastis permintaannya terhadap kenaikan pendapatan.

Rahardja \& Manurung (2008) mengemukakan faktor faktor yang mempengaruhi tingkat konsumsi dapat diklasifikasikan menjadi tiga besar yakni faktor ekonomi, demografi dan non

Tabel 4. Tingkat Partisipasi dan Rata-Rata Konsumsi lkan (Kg/Kapita/Tahun) Rumah Tangga Berdasarkan Kelas Pendapatan di DKI Jakarta, 2017.

\begin{tabular}{|c|c|c|c|}
\hline Kabupaten/ Kota Adm. & $\begin{array}{c}\text { Kelas } \\
\text { Pendapatan }\end{array}$ & $\begin{array}{l}\text { Partisipasi Konsumsi } \\
\text { Ikan (\%) }\end{array}$ & $\begin{array}{l}\text { Rata-Rata Konsumsi Ikan } \\
\text { (Kg/Kap/Tahun) }\end{array}$ \\
\hline \multirow[t]{3}{*}{ Kepulauan Seribu } & Rendah & 97,69 & 45,77 \\
\hline & Menengah & 100,00 & 52,89 \\
\hline & Tinggi & 100,00 & 68,70 \\
\hline \multirow[t]{3}{*}{ Jakarta Selatan } & Rendah & 68,32 & 20,26 \\
\hline & Menengah & 78,93 & 29,02 \\
\hline & Tinggi & 87,08 & 35,89 \\
\hline \multirow[t]{3}{*}{ Jakarta Timur } & Rendah & 71,62 & 25,87 \\
\hline & Menengah & 87,39 & 31,45 \\
\hline & Tinggi & 84,69 & 41,68 \\
\hline \multirow[t]{3}{*}{ Jakarta Pusat } & Rendah & 49,85 & 18,27 \\
\hline & Menengah & 60,96 & 16,88 \\
\hline & Tinggi & 76,42 & 23,98 \\
\hline \multirow[t]{3}{*}{ Jakarta Barat } & Rendah & 66,76 & 23,61 \\
\hline & Menengah & 85,11 & 25,12 \\
\hline & Tinggi & 88,37 & 33,75 \\
\hline \multirow[t]{3}{*}{ Jakarta Utara } & Rendah & 68,27 & 25,18 \\
\hline & Menengah & 82,24 & 31,70 \\
\hline & Tinggi & 93,18 & 37,82 \\
\hline
\end{tabular}


ekonomi. Faktor non ekonomi yang dimaksud diantaranya adalah faktor sosial budaya masyarakat. Konsumsi ikan di DKI Jakarta diindikasikan lebih banyak dipengaruhi faktor non ekonomi karena jika dilihat dari tingkat pendapatan rumah tangga di DKI Jakarta lebih sejahtera dibandingkan wilayah lainnya. Oleh karena itu, beberapa kajian juga mengaitkan konsumsi ikan dengan faktor non ekonomi, seperti hasil kajian Waysima et al. (2011) bahwa perilaku ibu menyediakan ikan laut untuk keluarga sangat dipengaruhi oleh persepsi ibu, sikap afektif ibu, wilayah tempat tinggal, pendapatan per kapita per bulan dan pendidikan ibu. Pola konsumsi juga dapat dipengaruhi oleh kebiasaan makan dimana menurut Kurniawati (2011) faktor yang mempengaruhi kebiasaan makan adalah jenis kelamin, umur, pendidikan ibu, pekerjaan ibu, tingkat pendapatan orang tua, pengetahuan ibu tentang gizi, sikap ibu tentang gizi, jumlah anggota keluarga dan pantangan. Berbagai hasil kajian di atas dapat menjadi acuan untuk penelitian lebih mendalam mengenai faktorfaktor non ekonomi yang diduga mempengaruhi tingkat konsumsi ikan rumah tangga di DKI Jakarta. Hal ini dapat memberikan gambaran yang lebih utuh faktor penyebab rendahnya konsumsi ikan di DKI Jakarta dibandingkan lokasi lainnya di Indonesia.

Data SUSENAS memungkinkan analisis untuk melihat preferensi terhadap 35 jenis kelompok ikan sesuai yang terdapat dalam kuesioner sehingga dapat melihat ikan mana yang paling banyak dikonsumsi oleh rumah tangga melalui nilai tingkat partisipasi konsumsinya. Hasil pengolahan data menunjukkan bahwa ikan yang paling digemari di provinsi DKI Jakarta adalah ikan kembung/lema/banyaran, ikan tongkol/tuna/cakalang, ikan lele, ikan teri awetan. Ikan bandeng dan ikan mas/nila. Oleh karena itu dalam upaya peningkatan konsumsi ikan menjadi perlu untuk meningkatkan ketersediaan pada ikan yang digemari oleh rumah tangga di DKI Jakarta.

\section{STRATEGI PENINGKATAN KONSUMSI IKAN DKI JAKARTA}

Peningkatan konsumsi ikan menjadi hal yang penting dilakukan dalam mengatasi masalah stunting di DKI Jakarta. Oleh karena itu jika dilihat dalam pokok bahasan pertama dan kedua maka dapat ditarik kesimpulan bahwa konsumsi ikan secara umum memiliki hubungan yang positif dengan tingkat pendapatan rumah tangga. Analisis lebih lanjut tingkat konsumsi ikan yang tertinggi bukan berada pada wilayah yang tingkat pendapatanya tertinggi dan konsumsi ikan yang terendah juga bukan berada pada wilayah yang tingkat pendapatanya paliing rendah. Konsumsi ikan yang tertinggi berada pada Kepulauan Seribu yang diduga karena aspek keterjangkauan terhadap ikan, sedangkan konsumsi ikan terendah pada wilayah Jakarta Pusat diduga karena aspek preferensi penduduk di wilayah ini.

Keragaan konsumsi ikan jika disimpulkan berdasarkan wilayah di DKI Jakarta menunjuukkan bahwa Kepulauan Seribu merupakan yang tertinggi konsumsinya. Kepulauan Seribu merupakan gugusan pulau yang terdapat di Teluk Jakarta dan Laut Jawa dimana sebagian besar penduduknya memiliki mata pencaharian sebagai nelayan menyebabkan ikan sebagi pangan sumber protein menjadi lebih terjangkau baik dari sisi harga maupun ketersediaanya bagi penduduk di Kepulaun Seribu. Jakarta Pusat merupakan wilayah dengan nilai stunting tertinggi, akan tetapi di wilayah ini konsumsi ikan lebih dipengaruhi oleh faktor non ekonomi dibandingkan daya beli rumah tangga. Oleh karena itu strategi peningkatan konsumsi ikan pada setiap wilayah tentunya berbeda yang dipengaruhi oleh aspek pendapatan dan juga preferensi di wilayah tersebut. Berdasarkan keragaan konsumsi ikan yang dijelaskan pada bagian sebelumnya maka secara ringkas strategi peningkatan konsumsi ikan dijelaskan dalam Tabel 5.

Pemerintah DKI Jakarta telah meluncurkan program ikan subsidi untuk meningkatkan keterjangkauan harga ikan terutama bagi rumah tangga kelas pendapatan rendah. Program ini diperuntukkan untuk buruh bergaji setara Upah Minimum Provinsi (UMP) DKI atau 10 persen di atas UMP DKI. Hal ini sudah tepat karena kondisi konsumsi ikan paling rendah ada pada rumah tangga kelas pendapatan rendah yang diduga disebabkan kurangnya daya beli. Akan tetapi, pada rumah tangga di Jakarta Pusat perlu mendapat perhatian utama karena angka stunting di wilayah ini tertinggi sedangkan angka konsumsi ikannya paling rendah baik dilihat dari tingkat partisipasinya yang kurang dari $60 \%$ dan juga konsumsi ikan perkapitanya. Oleh karena itu, Jakarta Pusat seharusnya menjadi fokus wilayah peningkatan konsumsi ikan di DKI Jakarta yang pada akhirnya diharapkan dapat membantu penanganan angka stunting di wilayah ini. 
Tabel 5. Strategi peningkatan konsumsi ikan berdasarkan wilayah di DKI Jakarta.

\begin{tabular}{|c|c|}
\hline Kabupaten/Kota Adm. & Strategi \\
\hline Kepulauan Seribu & $\begin{array}{l}\text { Perlu peningkatan kualitas ikan yang dikonsumsi dengan meningkatkan } \\
\text { pemahaman rumah tangga terhadap teknik pengolahan ikan, serta meningkatkan } \\
\text { kualitas ikan pada level produksi dan handling saat distribusi. }\end{array}$ \\
\hline Jakarta Selatan & $\begin{array}{l}\text { Peningkatan konsumsi ikan terutama pada rumah tangga kelas pendapatan rendah } \\
\text { dan menengah dengan meningkatkan keterjangkauan ikan dari sisi harga terutama } \\
\text { untuk jenis ikan kembung, lele, mas, nila, dan bandeng }\end{array}$ \\
\hline Jakarta Timur & $\begin{array}{l}\text { Peningkatan keterjangkauan ikan lele sebagai ikan yang paling digemari rumah } \\
\text { tangga kelas pendapatan rendah dan menengah. }\end{array}$ \\
\hline Jakarta Pusat & $\begin{array}{l}\text { Program peningkatan konsumsi ikan terpadu pada semua kelas pendapatan } \\
\text { dengan mengedukasi dan promosi secara berkala dan terus menerus terkait nilai } \\
\text { gizi terutama pada ikan segar. Peningkatan keterjangkauan harga ikan segar di } \\
\text { wilayah ini juga perlu dilakukan agar konsumsi ikan awetan beralih menjadi ikan } \\
\text { segar. }\end{array}$ \\
\hline Jakarta Barat & $\begin{array}{l}\text { Branding image ikan sebagai komoditas bergizi tinggi untuk meningkatkan } \\
\text { preferensi ikan pada semua kelas pendapatan dan perlunya peningkatan kualitas } \\
\text { ikan yang dan keterjangkauan hingga ke pasar modern. }\end{array}$ \\
\hline Jakarta Utara & $\begin{array}{l}\text { Promosi nilai gizi ikan dan edukasi bagaimana teknik pengolahan ikan sehingga } \\
\text { semakin banyak volume ikan yang dikonsumsi rumah tangga dan makin banyak } \\
\text { pula rumah tangga yang mengkonsumsi ikan. }\end{array}$ \\
\hline
\end{tabular}

Hasil studi Margawati \& Astuti (2018) merekomendasikan peningkatan pengetahuan gizi kepada ibu sehingga terjadi peningkatan, perbaikan pola asuh dan pola makan untuk menurunkan angka stunting, hal ini juga dapat dilakukan di wilayah DKI Jakarta khususnya Jakarta Pusat karena daya beli bukan merupakan faktor utama yang menyebabkan rendahnya konsumsi ikan di wilayah ini. Strategi yang dapat dilakukan harus berfokus pada promosi dan edukasi secara konsisten untuk meningkatkan kesadaran akan gizi dengan meningkatkan konsumsi pangan hewani. Selain itu kelompok rumah tangga pada kelas pendapatan tinggi juga perlu menjadi target gerakan peningkatan konsumsi ikan dan dapat berfokus pada upaya promosi dan dan peningkatan kualitas gizi ikan. Menurut Ariani (2012) sejalan dengan peningkatan pendapatan masyarakat dihadapkan pada banyak pilihan pangan tanpa kendala keuangan sehingga akan lebih memperhatikan aspek kualitas, kesehatan dan keamanan pangan. Hal tersebut menyebabkan promosi dan branding image terhadap ikan dianggap sebagai strategi yang tepat untuk rumah tangga pada kelas pendapatan tinggi.

\section{PENUTUP}

Konsumsi ikan rumah tangga di DKI Jakarta berhubungan dengan kelas pendapatan meskipun terdapat beberapa faktor lainnya yang juga mempengaruhi. Semakin tinggi kelas pendapatan pada suatu wilayah menunjukkan konsumsi ikannya yang semakin meningkat dari sisi tingkat partisipasi maupun tingkat konsumsi per kapita. Wilayah dengan konsumsi ikan yang tertinggi bukan wilayah dengan tingkat pendapatan yang tertinggi sehingga diduga terdapat faktor lainnya yang mempengaruhi konsumsi ikan selain pendapatan. Angka stunting tertinggi berada pada wilayah yang konsumsi ikannya paling rendah yakni Jakarta Pusat. Strategi peningkatan konsumsi ikan yang dapat dilaksanakan dengan peningkatan keterjangkauan dari ikan baik dari sisi harga maupun ketersediaanya di pasar sehingga program ikan subsidi yang sudah dilaksanakan oleh Pemerintah DKI Jakarta saat ini dianggap tepat dan perlu dilanjutkan. Program edukasi dan promosi terhadap seluruh lapisan masyarakat perlu diakukan karena rumah tangga pada kelas pendapatan tinggi di DKI Jakarta konsumsi ikannya rata-raa lebih rendah dari konsumsi ikan nasional. Fokus kebijakan peningkatan konsumsi ikan juga perlu untuk dilakukan di wilayah Jakarta Pusat sebagai wilayah dengan konsumsi ikan yang terendah dan angka stunting paling tinggi sehingga diharapkan program peningkatan konsumsi ikan di wilayah ini akan membantu menurunkan angka stunting.

\section{UCAPAN TERIMA KASIH}

Terima kasih penulis ucapkan kepada Ibu Estu Sri Luhur, M.Si dan Rismutia Hayu Deswati, ME yang banyak memberikan saran bagi 
penyempurnaan tulisan ini. Selain itu penghargaan penulis sampaikan kepada Pusat Data Statistik dan Informasi Kementerian Kelautan dan Perikanan yang banyak membantu terkait dengan pengadaan data bagi penelitian ini.

\section{DAFTAR PUSTAKA}

Ahmad NI. Rozita W. Mahiyuddin W. Tengku TR. Ling CY. Daud SF. Hussen NC. Abdullah NA. Shaharudin R. \& Sulaiman LH. (2016). Fish Consumption Pattern Among Adults of Different Ethnics in Peninsular Malaysia. Food and Nutrition. 1:1-15.

Amaliyah, H. (2011). Analisis Hubungan Proporsi Pegeluaran dan Konsumsi Pangan dengan Ketahanan Pangan Rumah Tangga Petani Padi di Kabupaten Klaten. Skripsi. Fakultas Pertanian. Universitas Sebelas Maret.

Ariani M. (2012). Rekontruksi Pola Pangan Masyarakat dalam Upaya Percepatan Diversifikasi Pangan Mendukung Program MP3EI. Dalam: Ananto EE, S Pasaribu, M Ariani, B Sayaka, NS Saad, K Suradisastra, K Subagyono, H Soeparno, F Kasryno, E Pasandaran, R Hermawanto., editors. Kemandirian Pangan Indonesia dalam Perspektif Kebijakan MP3EI. Jakarta (ID): IAARD Press.

Ariani, M., Suryana, A., Suhartini, S.H. \& Saliem, H.P. (2018). Keragaan Konsumsi Pangan Hewani berdasarkan Wilayah dan Kelas Pendapatan di Tingkat Rumah Tangga. Analisis Kebijakan Pertanian, 16 (2), 147-163. doi:10.21082/akp. v16n2.

Aridiyah FO, N Rohmawati \& M Ririanty. (2015). Faktor-faktor yang mempengaruhi kejadian stunting pada anak balita di wilayah pedesaan dan perkotaan. Jurnal Kesehatan. 3 (1): 163-170. Retrieved from :https://jurnal.unej.ac.id/index. php/JPK/article/view/2520/2029.

Arthatiani, F.Y., Kusnadi \& N., Harianto. (2018). Analisis Pola Konsumsi dan Model Permintaan Ikan Menurut Karakteristik Rumah Tangga di Indonesia. Jurnal Sosial Ekonomi Kelautan dan Perikanan, 13(1), 73-86.

Aydin H. Dileh MK. \& Aydin K. (2011). Trends in Fish and Fishery Product Concumption in Turkey. Turkish Journal of Fisheries and Aquatic Sciences.11: 499-506.

[BKP]. Badan Ketahanan Pangan. (2012). Roadmap Diversifikasi Pangan 2011-2015. Jakarta (ID): Kementerian Pertanian Republik Indonesia.

[BPS]. Badan Pusat Statistik. (2018). Pengeluaran Untuk Konsumsi Penduduk Indonesia Per Provinsi. Badan Pusat Statistik. Jakarta.
Dey MM. \& Alam MDF. \& Paraguas FJ. (2011). A Multistage Budgeting Approach to the Analysis of Demand for Fish: An Application to Inland Areas of Bangladesh. Marine Resource Economics. 26, 35-58.

Engel, F. James; Roger D. Blackwell; Paul W \&. Miniard. (2004). Perilaku Konsumen. Jakarta : Binarupa Aksara.

FAO. (2015). The Consumption of Fish and Fish Products in the Asia-Pacific Region Based on Household Surveys. Bangkok (Thai): Food And Agriculture Organization Of The United Nations Regional Office For Asia And The Pacific.

Hariyadi P. (2011). Importance and Role Of Protein In The Indonesia Daily Diet. Presented at "Whey Protein Health and Fitness Seminar. http://www.seafast. ipb.ac.id /publication/ presentation/ USDEC-Protein-Whey-Jakarta2011-handouts.pdf

[Kemenkes] Kementerian Kesehatan. (2017). Pemantauan Status Gizi Tahun 2017. Kementerian Kesehatan Jakarta.

[KKP] Kementerian Kelautan dan Perikanan. (2017). Kelautan dan Perikanan dalam Angka tahun 2017. Kementerian Kelautan dan Perikanan Republik Indonesia.

[KKP] Kementerian Kelautan dan Perikanan. (2018). Peta Kebutuhan Ikan: Berdasarkan Preferensi Konsumen Rumah Tangga Tahun 2017. Direktorat Pemasaran. Direktorat Jenderal Penguatan Daya Saing Kelautan dan Perikanan. Kementerian Kelautan dan Perikanan Republik Indonesia.

Kurniawati, S. (2011). Faktor-Faktor yang Berhubungan dengan Kebiasaan Makan Anak Usia Prasekolah (4-6 Tahun) di TK Al Amanah Kecamatan Sindang jaya. Kabupaten Tangerang. Tahun 2011. USkripsi. Universitas Islam Negeri Syarif Hidayatullah.

Margawati, A. \& Astuti, A.M. (2018). Pengetahuan Ibu, Pola Makan dan Status Gizi Anak Stunting 1-5 Tahun di Kelurahan Bangetayu, Kecamatan Genuk, Semarang. Jurnal Gizi Indonesia. 6(2): 2018.

Mayasari, D., Satria, D. \& Noor, I. (2018). Analisis Pola Konsumsi Pangan Berdasarkan Status IPM di Jawa Timur. Jurnal Ekonomi dan Pembangunan Indonesia, 18(2), 191-213. Retrieved from: https://jepi.fe.ui.ac.id/index.php/JEPI/article/ view/801/pdf_30.

Mitra. (2015). Permasalahan anak pendek (stunting) dan intervensi untuk mencegah terjadinya stunting (Suatu Kajian Kepustakaan). J. Kesehatan Komunitas. 2 (6):254-261. 
Ni'mah, K., \& Nadhiroh, S.R. (2015). Faktor yang Berhubungan dengan Stunting Pada Balita. Media Gizi Indonesia, 10(1),13-19. Retrieved form https:/ejournal.unair.ac.id/MGI/.

Pakpahan, A., H.P. Saliem \& S.H. Suhartini. (1993). Penelitian tentang ketahanan Pangan masyarakat Berpendapatan Rendah. Monograph Series No 14. Pusat Peneltian Sosial Ekonomi Pertanian / Bogor.

Purwaningsih, Y. (2008). Ketahanan pangan: situasi, permasalahan, kebijakan, dan pemberdayaan masyarakat. Jurnal Ekonomi Pembangunan: Kajian Masalah Ekonomi dan Pembangunan, 9(1), 1-27. DOI: https://doi.org/10.23917/jep. v9i1.1028.

Purwantini, T.B. (2012). Analisis Dinamika Konsumsi Pangan dan Kesejahteraan Rumah Tangga Petani Padi. Prosiding Litbang Pertanian. 508-522. Pusat Sosial Ekonomi dan Kebijakan Pertanian. Bogor.

Rahardja, P. \& Manurung, M. (2008). Pengantar IImu Ekonomi (Mikroekonomi dan Makroekonomi) Edisi Ketiga. Fakultas Ekonomi Universitas Indonesia. Jakarta.

Sari EM, M Juffrie, N Nurani \& MN Sitaresmi. (2016). Asupan protein, kalsium dan fosfor pada anak stunting dan tidak stunting usia 24-59 bulan. Jurnal Gizi Klinik Indonesia, 12 (4): 152-259.

Soedjana, T., D. (2013). Partisipasi Konsumsi sebagai Alat Ukur Status Ketahanan Pangan Daging. Wartazoa. 23(4), 165-175. Retreived from: http:// medpub.litbang.pertanian.go.id, index.php , wartazoa > article > download.

Suryanti, M., \& Reswita. (2016). Analisis Konsumsi Pangan Berbasis Protein Hewani di Kabupaten Lebong: Pendekatan Model AIDS (Almost Ideal Demand System). AGRISEP, 16(1), 101-110.

Survey Sosial Ekonomi Nasional (SUSENAS). (2017). Badan Pusat Statistik: Jakarta.

Umeta M, West CE, Verhoef H, Haidar J, \& Hautvast J. (2003). Factors associated with stunting in infants aged 5-11 months in the dodota-sire district, rural Ethiopia. J. Nutrition. 133(4):1064-1069.

Waysima, S.U., A. Khomsan, \& F.R. Zakaria. (2011). Persepsi dan Sikap Afektif Mempengaruhi Perilaku Ibu Menyediakan Ikan Laut dalam Menu Keluarga. Jurnal IImu Keluarga dan Konsumen. 4(1): 74-81.

[WHO] World Health Organization. (2014). WHA global nutrition targets 2025: Stunting policy brief. Geneva: World Health Organization.

Wiseman G. (2002). Nutrition and Health. Taylor \& Francis, London.
World Bank. (2014). Kajian Kebijakan Pembangunan 2014:Indonesia Menghadapi Perangkap. Jakarta: The World Bank 